Marquette University

e-Publications@Marquette

College of Communication Faculty Research and

Publications

Communication, College of

$11-1-2007$

Sex and Shock Jocks: An Analysis of the Howard Stern and Bob \& Tom Shows

Lawrence Soley

Marquette University, lawrence.soley@marquette.edu

Accepted version. Journal of Promotion Management, Vol. 13, No. 1/2 (November 2007): 73-91. DOI. (C) 2007 Taylor \& Francis (Routledge). Used with permission. 


\title{
Sex and Shock Jocks: An Analysis of the Howard Stern and Bob \& Tom Shows
}

\author{
Lawrence Soley \\ Diederich College of Communication, Marquette University \\ Milwaukee, WI
}

\begin{abstract}
Studies of mass media show that sexual content has increased during the past three decades and is now commonplace. Research studies have examined the sexual content of many media, but not talk radio. A subcategory of talk radio, called "shock jock" radio, has been repeatedly accused of being indecent and sexually explicit. This study fills in this gap in the literature by presenting a short history and an exploratory content analysis of shock jock radio. The content analysis compares the sexual discussions of two radio talk shows: Infinity's Howard Stern Show and Clear Channel's Bob \& Tom Show.
\end{abstract}

\section{Introduction}

The quantity and explicitness of sexual content in mass media has steadily increased during the past three decades. Greenberg and Busselle (1996) found that sexual activities depicted in soap operas increased between 1985 and 1994, rising from 3.67 actions per hour in 1985 to 6.64 per hour in 1994. Kunkel et al. (2001) found that the percentage of television programs with sexual content increased from $56 \%$ during the $1997 / 1998$ season to $68 \%$ during the $1999 / 2000$ season. In a study of 2001 television programming, Fisher et al. (2004) found that $78.8 \%$ of broadcast network programming 
NOT THE PUBLISHED VERSION; this is the author's final, peer-reviewed manuscript. The published version may be accessed by following the link in the citation at the bottom of the page.

contained sexual content. Over $95 \%$ of the movies airing on premium cable channels contained sexual content, as did feature films shown on the commercial television networks.

Sommers-Flanagan and colleagues (1993) found that ninetenths of the 30-second intervals in a sample of MTV music videos contained sexual materials. In a study of sexual content in media to which adolescents were exposed, Pardun et al. (2005) found that music contained the most sexual content, outstripping television, movies and magazines. The majority of the sexual content dealt with romantic relationships, but $15 \%$ concerned sexual intercourse. Pardun et al. (2005) also found a significant relationship between exposure to sexual materials and adolescents' sexual activity.

Sexual content on the internet is also pervasive. For example, studies conducted for the US General Accounting Office and House Committee on Government Reform showed that over $50 \%$ of the video files retrieved on file-sharing servers such as Kazaa using seemingly innocent search terms such as "Britney" and the "Olsen twins" contained pornography (Krim, 2003). The use of sexual appeals in advertisements has also increased over time. Reichert et al. (1999) showed that the percentage of magazine ads portraying intimate sexual behavior more than doubled between 1983 and 1993.

These studies demonstrate that sexual content in the media has increased, and is abundant on the internet, music, music videos, television, films, and magazine advertisements, but no study has yet systematically studied the sexual content of talk radio shows, particularly "shock jock" shows. Shock jocks have been criticized for their sexual-and some say, obscene-discussions. The term "shock jocks" originated with critics employed by other media, who developed the term to describe radio shows containing "a panoply of sexual and scatological references" and cultural and ethnic insults (Feldman, 2004, p. 1261).

This study fills in the gap in the research by presenting a short history of shock jock radio shows and a content analysis of one week of the Howard Stern Show and the Bob \& Tom Show. Both drive-time radio programs receive high ratings where they air, and may well set

Journal of Promotion Management, Vol. 13, No. 1/2 (2007): pg. 73-91. DOI. This article is @ Taylor \& Francis (Routledge) and permission has been granted for this version to appear in e-Publications@Marquette. Taylor \& Francis (Routledge) does not grant permission for this article to be further copied/distributed or hosted elsewhere without the express permission from Taylor \& Francis (Routledge). 
the standards for sexual content of other media. Stern says, "I changed the way people speak on TV. I changed the way people talk on the radio.... When I first got into radio, TV never used the word 'penis' on the air" (Stern, 2002). Stern is regarded as a shock jock, whereas Bob and Tom are not.

\section{Origins of "Shock Jock" Radio}

The direct predecessor of shock jock radio is the "topless radio" format that developed in the early 1970s. This format originated in Los Angeles with Storer Broadcasting-owned station KGBS-AM/FM, which assigned nighttime disk jockey Bill Balance as host of a live, daytime call-in show titled Feminine Forum (McLellan, 2004). Women were invited to call the Feminine Forum and discuss that day's issue, which was usually a romantic or sexual topic (Carlin, 1976; McLellan, 2004).

Although originally targeted to women, the show attracted many men, and after a year-and-half captured the number one rating in the city. The show's popularity led to its being syndicated and imitated. Similar shows appeared in New York, Detroit, Cleveland, Washington, DC, Dallas, and Chicago (Shipler, 1973; Carlin, 1976). Some imitators, such as the Feminine Forum program carried on Sonderling Broadcasting Co.'s WGLD-FM in Chicago, had far more sex-laden discussions than Balance's show.

Federal Communications Commission (FCC) chairman Dean Burch listened to tapes of these broadcasts and the following month at the National Association of Broadcasters convention excoriated "the prurient trash that is the stock-and-trade... of the smut-hustling host" (Krebs, 1973, p. 94). Burch was not just responding to what he heard on the tapes, but to a reported 3,000 obscenity complaints received by the FCC about the programs. Two weeks later, the FCC fined WGLD-FM for airing indecent programs focusing on oral sex, where callers were invited to discuss their experiences on-air (FCC, 1973). Rather than challenge the fine, Sonderling paid it and then halted the talk show. Other stations also dropped their programs.

The radio industry's rapid submission to the FCC was due to several factors: First, fears that industry expansion would be hurt if 
the programs continued; second, topless radio's contribution to station profits was small; and third, industry executives believed that the Nixon-appointed FCC would revoke station licenses for the continued airing of these shows. A radio station manager summed up the first factor, saying, "We are a member of a group that operates a number stations and are going to cable TV, and our growth depends on FCC approval." Another noted, "We didn't feel it was a big enough part of our format to be worth the hassle" (Krebs, 1973, p. 94). Lastly, the FCC had a decade earlier refused to renew the license of a Kingtree, South Carolina station for programming that was "course, vulgar, suggestive and of indecent double meaning." The FCC's decision was upheld in court (Robinson v. FCC, 1964).

\section{Don Imus}

Don Imus, host of the syndicated Imus in the Morning Show, is considered the pioneer of "shock jock" radio (White, 1995), but the format is actually a fusion of "topless" and insult radio, which was pioneered by Joe Pyne. Imus's radio career began in Sacramento in 1968, where he developed a reputation for, and increased his popularity by, making prank phone calls, hurling insults and making lewd comments. This strategy was copied by subsequent shock jocks, who continuously increased the sexual content of their shows. Imus's success in Sacramento allowed him to move to larger markets, first Cleveland then New York, where the same combination of antics attracted high ratings (Goldstein, 2000).

Imus's national prominence is linked to Infinity Broadcasting Corp.'s purchase in 1992 of WFAN-AM in New York. The station was purchased to ensure that Infinity had a major presence in the New York market, and because Infinity chairman Mel Karmazin viewed Imus's show as an established "franchise" that could be nationally syndicated. When added to Infinity's rock station, WXRK-FM, which carried Howard Stern in the morning, Infinity captured nearly 16 percent of 25-54 olds, the largest percentage being male (Colford, 1992). Infinity's strategy was to attract younger, "rock and roll" males with Stern on the rock station, and older, better-educated males with Imus on WFAN, and to then syndicate the shows to other stations. 
In order to attract a better-educated audience, and to attract celebrities to interview, Imus abandoned the crudest elements of his show, leading some commentators to describe him as a "former shock jock" (Feldman, 2004). This, in turn, attracted higher profile celebrities, and made the program more palatable for Midwestern markets, such as Sioux City and Fargo, where stations have carried the program (Marcotty, 1995). An example of Imus's toned-down comments are typified by a 2005 interview with conservative Sen. Rick Santorum (R-PA), who appeared on Imus in the Morning to discuss his book, It Takes a Family: Conservatism and Common Good. Imus said to Santorum, "You have six kids. Can I ask you a personal question?" Santorum said, "Yes," and Imus asked, "Have you had sex with Mrs. Santorum more than six times?" Santorum replied "yes" again, and the interview continued as before (Eisele and Dufour, 2005).

Imus views his show as competing with news and classic rock programs for better educated males, in contrast with Stern's program. "By the nature of what we do, you're limiting the audience ....It's a high-end audience," unlike the one attracted to Stern, Imus says (Ostrow, 1995). Imus reportedly dislikes Stern not just because of Stern's higher ratings, but because he views Stern as a vulgar imitator.

\section{Howard Stern}

Like Imus, Stern is a product of Infinity Broadcasting. He began as a radio personality in Connecticut, and then moved to larger stations in Detroit and Washington, DC. Stern returned to his hometown of New York in 1982, after landing a show on NBC's flagship station, WNBC-AM. He was fired from there in 1985 for broadcasting a skit, "Bestiality Dial-A-Date," but was quickly picked up by Infinity's WXRK-FM. The following year, Infinity Broadcasting started syndicating Stern's show, which featured interviews with strippers, pornographers, prostitutes and second-tier celebrities (Flint, 1992).

In the Los Angeles, Philadelphia and Washington, DC markets, where his show has been syndicated, Stern was number one in ratings among men 18-34 during the early 1990s. After putting Stern on KLSX-FM in Los Angeles, the station was able to quadruple its morning

Journal of Promotion Management, Vol. 13, No. 1/2 (2007): pg. 73-91. DOI. This article is @ Taylor \& Francis (Routledge) and permission has been granted for this version to appear in e-Publications@Marquette. Taylor \& Francis (Routledge) does not grant permission for this article to be further copied/distributed or hosted elsewhere without the express permission from Taylor \& Francis (Routledge). 
drive-time rates (Viles, 1992). Although Stern's ratings faltered over the years, he returned to the number one spot in New York and Los Angeles in 2004 (Pugh, 2004). These ratings have created for Stern a loyal advertising base, including Anheuser-Busch, Cingular Wireless and Toyota, which have been reluctant to terminate advertising on his show despite pressure from such groups as the American Decency Association (American Decency Association, 2004).

The profitability and popularity of Stern's show explains why the radio industry responded differently to FCC complaints about indecency in the 1990s than to complaints about "topless radio" in the 1970s: The profits generated by shock jock programming exceeded the fines levied by the FCC. Thus, stations continued to air, and Infinity continued to distribute, the Howard Stern Show even after the FCC repeatedly fined Infinity Broadcasting for Stern's indecency (Ahrens, 2005). Moreover, Clear Channel decided to carry Stern's show on their stations after the FCC concluded that the show's content had been indecent (Petrozello, 1996; Stern, 1995), suggesting the corporation was less interested in decency than profits.

Other reasons for the different response was that the industry had consolidated, creating much larger, more secure corporations; shock jock programming had become a bigger and more profitable part of radio programming than "topless" radio was; and the industry was more willing to challenge the FCC on First Amendment grounds. The largeness of the radio industry, and the importance of shock jocks, is exemplified by Infinity Broadcasting, which acquired Westwood and Unistar networks, in part to distribute its talk shows, which included shock jocks Don Imus, Howard Stern, and Doug "The Greaseman" Tracht (Vilas, 1993a, 1993b). Infinity is now part of Viacom, one of the world's largest media companies.

Broadcasting companies assert that shock jocks are protected by the First Amendment because of the increased protection accorded indecent speech by court decisions such as Reno v. ACLU (1997), and because many shock jocks espouse political philosophies on their shows. For example, shock jocks Howard Stern and "Mancow" Muller espouse libertarianism, leading them to criticize "politically correct" Democrats like former President Bill Clinton. and permission has been granted for this version to appear in e-Publications@Marquette. Taylor \& Francis (Routledge) does not grant permission for this article to be further copied/distributed or hosted elsewhere without the express permission from Taylor \& Francis (Routledge). 
Part of Stern's appeal to 18-34 year-old males is because of his opposition to "political correctness." As one listener put it, "I like the fact that that with all the political correctness in the world, he is antipc" (Pugh, 2004, E8). In contrast with Imus, who interviews but nevertheless criticizes Democrats and Republicans, Stern has used his show to promote anti-pc political candidates, whose laissez faire attitudes Stern favors. Stern endorsed such candidates as President Ronald Reagan, gubernatorial candidates George Pataki, Christine Todd, and Arnold Schwarznegger, and mayoral candidate Rudolph Giuliani (Marinucci, 2004; Ferguson, 2004). Despite his favoring Republican candidates, traditional conservative organizations have been Stern's most vocal critics.

Stern shifted political allegiances in 2004, announcing that he opposed President George W. Bush's re-election. The major reason for the shift was that Bush appointee Michael Powell led a FCC crackdown on indecent broadcasting, which Stern viewed as an attack on him (Ferguson, 2004). Several days after Stern's announcement, Clear Channel suspended and then dropped Stern's show from six stations, saying that its decision was based on Stern's refusal to abide by FCC indecency rules or the corporation's new "zero tolerance" policy, adopted after Clear Channel was fined for indecency by the FCC. Stern claimed the decision was based on his opposition to Bush.

In 2004, Stern signed a $\$ 500$ million, five-year contract with Sirius Satellite Radio to appear on that network beginning in 2006, claiming that being on satellite would allow him to escape FCC "censorship" (Klaassen, 2005). Stern repeatedly mentioned his impending move to Sirius during broadcasts, causing a displeased executive with Citadel Broadcasting Corp., whose stations carried Stern's show, to plead with Stern's producer "to get Howard back to the T and A and the filth, and off satellite" (Day, 2005). When Stern did not stop, Citadel dropped him from its stations and temporarily replaced him with the shock jock Opie \& Anthony Show under an agreement with Sirius's rival, XM Satellite Radio (Reuters, 2005; Bachman, 2004). 
NOT THE PUBLISHED VERSION; this is the author's final, peer-reviewed manuscript. The published version may be accessed by following the link in the citation at the bottom of the page.

\section{Mancow}

After Stern announced his move to satellite, Infinity Broadcasting began looking for a substitute for Stern. One of the individuals Infinity courted was Eric "Mancow" Muller, another politically conservative shock jock (Feder, 2005). Muller, a San Francisco area shock jock in the early 1990s, gained notoriety by stopping Bay Bridge traffic for a haircut to ridicule President Clinton for allegedly tying up Los Angeles air traffic while getting a $\$ 200$ trim (Kettmann, 1993). Using similar stunts, Mancow earned a reputation and following, which allowed him to move to Chicago, a larger market. In Chicago, Mancow hosts Mancow's Morning Madhouse on Emmis Communications' WKQX-FM, an album-oriented rock station. The show is syndicated to 20 stations by Talk Radio Network.

Mancow's show appeals to male virility with a combination of conservatism, militarism and sex. His followers are described as members of Mancow's Militia, and his website (www.Mancow.com) includes images of partially nude women holding weapons. T-shirts sold by Mancow read, "Kill a Satanist for Christ." An example of the way that Mancow mixes patriotism and sex is exemplified by an interview with statutory rapist Joey Buttafuoco, who discussed the Moonlight Bunny Ranch, a legal brothel (Q-101, 2003). The Bunny Ranch's owner, Dennis Hof, offered free sex to American soldiers who finished a tour of Iraq. As a result of broadcasts such as these, Mancow has succeeded in generating higher ratings in some markets than Stern (Smith, 2005).

Like Stern, Mancow was been cited by the FCC for indecent broadcasting, including one segment where a porn star graphically described "fisting" and another where women were interviewed about whether they "spit or swallowed" after engaging in oral sex (FCC, 2002, 2004). Also like Stern, Mancow has been the target of conservative critics, despite his self-professed conservatism. As an example, David Smith of the Illinois Family Institute filed 66 complaints about Mancow's indecency with the FCC (Feder, 2004).

Despite paying $\$ 42,000$ in fines for the indecent content of Muller's show, Emmis Communications continued to air it, suggesting 
that the company is less interested in morality than money. However, Muller claims that he is changing the content of the show to more accurately reflect his Christian outlook. "When I was 22, it was interesting to talk to porn stars ...I'm just not there anymore," Muller claims (Smith, 2005).

\section{The "Bob \& Tom Show"}

The Bob \& Tom Show is hosted by Bob Kevoian and Tom Griswold, who have been doing the show for over twenty years. The program is classified as a comedy program and has been syndicated to radio stations since 1995 by Premiere Radio Networks, a Clear Channel subsidiary (Premiere Radio Networks, 2003). The program originates on classic rock station WFBQ in Indianapolis, a Clear Channel station. The Bob \& Tom Show is syndicated in the morning to over 150 stations nationwide and is targeted to somewhat older males who listen to classic rock, but is also carried by alternative rock stations that target younger males, Stern's target market. Although not usually classified as a "shock jock" program, the show has been cited by the FCC for indecency (FCC, 2000).

Bob and Tom are joined on-air by Kristi Lee, the program's female "news director," and Chic McGee, the program's "sports director." Other personnel call the show and pretend to be Larry King, Bill Clinton, George Bush, Dr. Phil, and other, less well-known characters. The show consists of humorous songs and skits, news segments that are interrupted with comments and jokes, and telephone interviews with celebrities or near-celebrities, such as Mark Vancil, co-author of Michael Jordan's autobiography, and former talk show host Dick Cavett. The show usually includes having stand-up comics present in the studio, who integrate their comedy routines into the show.

The format is similar to that of the Howard Stern Show, which also has a female news announcer, Robin Quivers. Quivers joins Stern on-air with an assortment of other talking heads, who have included comic Artie Lange, John Melendez, Gary Dell-Abatte, and KC Armstrong, who was fired in 2004 after fabricating a story to generate 
publicity for a gambling website. Stern takes calls from listeners and does celebrity interviews.

The Bob \& Tom Show is scripted with the skits, songs and phone calls that revolve around daily themes, to which the personalities repeatedly return. The themes of the day are inspired by news stories and listeners' comments or questions.

The Howard Stern Show is scripted, but far less so than the Bob \& Tom Show, making it appear more spontaneous and less predictable than its competitor. Like the hosts of the Bob \& Tom Show, Stern frequently has a daily theme to which the personalities repeatedly return, or around which the program is focused.

The Bob \& Tom Show was selected for comparison with shock jock Howard Stern's broadcasts because it is one of the most widelysyndicated talk shows targeted to males, and originates on a station operated by Clear Channel, which now claims to have a "zero tolerance" policy toward indecency. The program should therefore serve as a benchmark, with which to compare the sexual content of the Howard Stern Show, as well as serving as a measure of the sexual content on large, corporate-owned programs.

\section{Method}

This study consists of an exploratory content analyses of the Howard Stern Show and the Bob \& Tom Show, comparing the two for sexual content. A week of Howard Stern Show broadcasts from June 24-28, 2002 was obtained from the American Decency Association, which has a library of taped Stern broadcasts. Over one hour of the programming on the tapes was inaudible. Thus, under 19 hours of the show were actually analyzed.

The researchers asked for these broadcasts because they: (1) Predated the FCC's attempts to curb indecency following the bearing of Janet Jackson's breast during the 2004 Super Bowl half-time show; (2) preceded Stern's decision to move to Sirius; and (3) preceded Stern's about-face on supporting President Bush. Thus, the broadcasts should 
NOT THE PUBLISHED VERSION; this is the author's final, peer-reviewed manuscript. The published version may be accessed by following the link in the citation at the bottom of the page.

be typical of Stern broadcasts during the late 1980s, 1990s and early 2000s.

Stern's show is on the air five hours each weekday morning, but just under four hours is actual programming. The Stern show employs 13-minute cut-aways, during which commercials and news segments are aired by the radio stations. The show was also carried for 11 years by the E! Cable channel, and was that network's highest rated program until ending its run in July 2005 (Broadcasting and Cable, 1994; Wallenstein, 2005).

The Bob \& Tom Show is on the air weekdays between 6 and 10 a.m. EST. The content of this show was analyzed by randomly sampling shows airing between October 25 and November 15, 2005. This time period follows Clear Channel's dropping Stern from their stations, and follows the FCC's reported attempts to curb indecency on radio. It should therefore be indicative of the content of radio in the "post-2004 Super Bowl" era.

\section{Coding}

An attempt was made to code the radio shows using coding categories developed in previous studies (e.g., Greenberg and Busselle, 1996, p. 155), where references to "prostitution, rape, homosexuality, intercourse among individuals married to each other" and other sexual activities were coded, but these categories proved inadequate and unreliable, given the varied nature of sexual discourse on the radio shows. As an example of the difficulties, Bob \& Tom Show daily themes included a report about a woman who glued her ex-boyfriend's "manhood" to his stomach; nude beach behavior; a vibrator that can be attached to an iPod; and a life-size, nude blow-up doll of news director Kristi Lee, all of which elicited numerous comments that did not reliably fit previously-used categories.

Consequently, a much simpler, but reliable method was used for the coding, which consisted of coding ten-minute segments of each broadcast as to whether they contained or did not contain sexual content. Sexual content was described as references to breasts, genitals and anuses; nudity and partial nudity; intercourse, oral sex,

Journal of Promotion Management, Vol. 13, No. 1/2 (2007): pg. 73-91. DOI. This article is @ Taylor \& Francis (Routledge) and permission has been granted for this version to appear in e-Publications@Marquette. Taylor \& Francis (Routledge) does not grant permission for this article to be further copied/distributed or hosted elsewhere without the express permission from Taylor \& Francis (Routledge). 
anal sex, intimate touching and arousal; prostitution and stripping; masturbation; semen; menstruation; adult bookstores, theaters, toys and pornography, including references to blow-up dolls; and double entendres for these, which the FCC has ruled can be indecent (FCC, 2000). Although it might be argued that anal references are not necessarily sexual, comments on the radio shows demonstrate they are. For example, during a discussion of clothing on the Bob \& Tom Show, a male described some young women as wearing "little teeny sweatpants that say 'juicy' right above their buttocks" (November 11).

References such as "giving the finger" or referring to someone as a "bitch" or "queer" were not coded as sexual, unless combined with any of the above sexual references. However, referring to a woman as a "nut cracker" was, because the term includes a reference to male genitals. Similarly, words such as "friggin" were not coded as sexual.

Using this definition, three different judges analyzed 18 tenminute segments of the Howard Stern Show. At least two coders analyzed each segment, producing $88.8 \%$ agreement. Disagreements focused primarily on whether epithets such as "whore" constituted sexual content. The coding nevertheless proved reliable (Scott's pi $=$ .82). Another 79 ten-minute segments of the Howard Stern Show and 87 ten-minute segments of Bob \& Tom Show segments were analyzed by a single judge.

\section{Results}

Of the Howard Stern Show segments, 73.2\% (i.e., 71 of 97) had sexual content. A slightly higher percentage of segments on the Bob \& Tom Show (78.6\%) contained sexual content. These two percentages do not differ significantly ( $z=-.85$, using a difference of proportions test), suggesting that the number of segments containing sexual materials on both shows is similar.

Although the number of segments containing sexual references does not differ, a qualitative analysis shows that the programs differ in terms of their focus on sex. First, interviews conducted on the Howard 
NOT THE PUBLISHED VERSION; this is the author's final, peer-reviewed manuscript. The published version may be accessed by following the link in the citation at the bottom of the page.

Stern Show focus heavily on the sexual activities of the interviewee, as shown by the following questions asked of JAG television actress Catherine Bell (June 28):

HS: When did you start having sex? How old were you?

HS: (about being taught by nuns): The school you went to, did they discourage you from masturbating?

HS: (about Bell's husband): How long did it take you to bang him after you met him?

HS: (about Bell's relationship with her husband): Would you ever bring another woman in the sack?

HS: Is size important to you? Size, yeah, men's size-penis size? HS: You ever made a made a home porno with him?

Bell answered some questions, such as about her first sexual encounters, and answered, "It's not my thing," to questions about bisexuality and home pornography. The only time she became indignant was when Stern ridiculed her belief in Scientology.

Similarly, actor David Arquette was asked the following questions about his relationship with his wife, actress Courteney Cox (June 25):

HS: Have you ever banged her without a rubber?

HS: Have you ever done anal with her?

HS: Do you ever take home porno of Courteney? Like, do you guys ever make your own porno?

HS: Would you ever give Courteney an enema ...I'm talking about a sexual enema?

Stern's questions are designed to make interviewees engage in explicit sexual discussions. Bob \& Tom Show interviews are the opposite-they usually avoid sexual discussions, although Mark Vancil's interview about Michael Jordan ended with a request for Jordan's email address, and a quip about sending him a spam email for a "penis extender."

Second, the news segments on the two shows are the opposite: The Bob \& Tom news segments usually focus on sexual topics, which and permission has been granted for this version to appear in e-Publications@Marquette. Taylor \& Francis (Routledge) does not grant permission for this article to be further copied/distributed or hosted elsewhere without the express permission from Taylor \& Francis (Routledge). 
lead to short sexual discussions, whereas the Howard Stern Show news reports are usually about non-sexual matters that may or may not lead into sexual discussions. As examples, news segments on the Bob \& Tom Show included reports about Lauren Hutton posing in the nude at 61 years of age; a sex party on Lake Minnetonka sponsored by Minnesota Vikings players; a Serbian physician's claim that he can induce temporary infertility in men by transmitting a mild electrical current through testicles; a report about an adult video producer being sued in Great Britain for false advertising; and two Carolina Panthers cheerleaders being arrested after engaging in sex acts in a restroom at a Tampa bar, all of which are real news stories. Such stories led to numerous sexual comments, such as referring to Minnesota Vikings quarterback Dante Culpepper as "Cul-pecker"; and discussions of lesbianism in sports, dotted with comments such as the Women's National Basketball Association not wanting "to use the phrase, 'Take it to the hole'"' (October 26).

In contrast, news reports on the Howard Stern Show are usually, but not always, about popular culture, celebrities and entertainment, which Stern or his co-hosts often turn toward sexuality. For example, a news report that actress Daryl Hannah was dating magician David Blaine led Stern to complain, "David Blaine is banging Daryl Hannah ... Who's he to be banging her?" (June 24). A discussion about a forthcoming calendar featuring Stern's girlfriend, model Beth Ostrosky, led KC to comment, "I had this calendar with hot Asian chicks. I must have pleasured myself three times a week to that calendar" (June 28). A report and discussion about the death of The Who bassist John Entwhistle resulted in a remark about Peter Townsend's friendship with Beth Ostrosky. This led Artie to comment, "The guy must be trying to get in her pants" (June 28).

Not all Stern news reports are about celebrities. A June 28 broadcast concerning a report that most women are wearing the wrong sized bra led to a 45-minute discussion about bras and breasts, during which Stern reportedly measured a female college student for a bra, commenting about the size of her "boobs" and observing, "In college, I would have banged you so hard you wouldn't have known what hit you." Stern also interviewed the woman about her sex life, and after learning that she shaved all over, offered her money and and permission has been granted for this version to appear in e-Publications@Marquette. Taylor \& Francis (Routledge) does not grant permission for this article to be further copied/distributed or hosted elsewhere without the express permission from Taylor \& Francis (Routledge). 
other inducements to remove her bikini bottom, saying, "Do you totally shave? Everything shaved off? Boy, that's hot. What kind of money does it take to get those bottoms off?" She reportedly removed them.

These and the previously quoted statements demonstrate a major difference between the sexual content of the Stern and the Bob \& Tom shows: Stern broadcasts usually concern personal sexual gratification, whereas Bob \& Tom's do not. Paying a woman to remove her bikini bottom produces sexual excitement for Stern-and titillation by audio voyeurism for listeners-and little else. Discussions of nude beach decorum as were carried on the Bob \& Tom Show do not focus on individual sexual gratification, and might even produce the opposite. For example, "Larry the Cable Guy" said that most young men go to nude beaches with false expectations, saying, "Let's go see some boobies." Bob commented that their expectations are that all the women will "look like Playboy centerfold models." "Instead, there are old women bending over with their boobs hanging down like a 7-11 split," Larry says (October 25). Thus the comments, while sexual, do not concern individual sexual gratification, but disappointment. This distinguishes much Howard Stern Show content from Bob \& Tom Show airings, and may well distinguish indecency from crudity.

Third, the analysis shows that Kristie Lee and Robin Quivers serve different functions on the two radio shows. Kristie serves as a tempering voice, often claiming to be embarrassed about discussions of sexuality, such as her comments about the nude Kristie Lee blow-up doll shown on the Bob \& Tom website. "It isn't funny if my 7 year-old daughter sees it," she said. On the other hand, Robin Quivers' comments differ little from the males' comments on the Stern show, and often encourage sexual discussion. As an example, Artie commented about actress Jaime Bergman, "What kind of lens do you have to use to get Jaime Bergman's breasts on screen ... They're enormous." Quivers concurred, saying with a laugh, "I've never seen a bra top for a bikini that big" (June 24). 
NOT THE PUBLISHED VERSION; this is the author's final, peer-reviewed manuscript. The published version may be accessed by following the link in the citation at the bottom of the page.

\section{Discussion}

Approximately three-fourths of the 10-minute segments analyzed for this study contained sexual content. The percentages were nearly the same for shock jock Howard Stern's program and the comedic Bob \& Tom Show, which raises the question: What is the difference between shock jocks and other morning radio talk show personalities? A qualitative analysis of the content suggests that they are distinguishable only by degree: Shock jock programming focuses more on individuals' sexual gratifications, whereas the other programming does so to a far lesser degree. There is a difference between asking David Arquette if he engages in anal intercourse with his wife, as Stern did, and airing a segment about "Herbie the Love Hummer," a homosexual vehicle, who "slams on his brakes" and says, "Hey, What does a guy have to do to be rear-ended around here?" as the Bob \& Tom Show did. Stern's approach gives one a personal lookmake that a leer-into the sexual activities of individuals, which Bob and Tom's sexual comments do not.

Both broadcasts use a variety of synonyms for breasts (i.e., "boobies" and "cans"), penises (i.e., "peckers" and "weiners"), female pubic areas ("beavers" and "fur burgers"), semen ("DNA" and "mayonnaise") and nearly every other sexual activity. Although both shows use similar terminology, the terms are used differently on the shows: Howard Stern individualizes the terms, whereas Bob and cohost Tom do not. An example of this is provided by Stern's interview with Catherine Bell: Stern says that her breasts are large and inquires, "Are they real?" Stern then says, "That's a D-cup bra" and laughing says, "I'll measure you." During a discussion of a nude photograph of Catherine Bell, Stern asserts he can see her "fur burger." In contrast, the Bob \& Tom duo refer to the "huge, heaving breasts" and "big breasted women" that can be seen wearing Birbiglia brand tank tops on their website.

The frequency with which sexual comments are made on both radio programs undoubtedly exceeds the frequency of sexual discourse in everyday life, suggesting that programs do not merely reflect sexual norms, as some theorists have suggested. The frequency with which sexual content appears in the programs suggests that it is used to 
attract and maintain male listeners, creating an unreal, sex-filled environment. On Stern's show, this fantasy world is taken to an extreme, where men are allowed to make comments to a woman about her breasts, ask a woman to remove her bikini bottom, or ask whether she has "orgied" or had lesbian experiences. This conclusion about a sex-filled, male fantasy world is supported by the terms used on the programs, such as "beaver," "hole" and "fur burger," that is part of the vocabulary of younger men, not women, and by the way that sexual material on the show's websites are mentioned to induce listeners to go to the websites.

Last, the analysis shows that explicit sexual content is common, even on radio shows originating on Clear Channel, which has adopted a "zero tolerance" policy toward indecency. Although Clear Channel and Infinity might claim that their program content is not indecent, this is something that the FCC determines, largely based on listener complaints.

\section{Conclusions}

The sexual content of talk radio shows is far more graphic than the sexual content of other broadcast or major print media, providing support for Stern's contention that he and other radio hosts set the standard for sexual permissiveness in other media. As an example of this graphicness, Stern opened his show on June 26, complaining about the underwear he was wearing, having switched from boxers to briefs to look sexier. About the briefs, Stern complained, "I want to hang free ... I want to arrange it so my wiener isn't so stifled... My balls feel stifled, all crunched together. I like everything to loosely hang." Clearly, Stern engages in far more graphic, on-air sexual discussions than found in other media, establishing a standard of what is legally acceptable for broadcast discourse.

Other radio programs, such as the Bob \& Tom Show, also engage in considerable, graphic sexual discussion, even using words that violate the "seven dirty words" standard. As an example, Bob spelled out the name of a Thai newspaper on air, "The P-h-u-k-e-t Gazette," and challenged his co-hosts to pronounce it (November 11). One readily volunteered, "It's 'fuck it."' 
These types of discourse occur on a daily basis and are found in nearly three-fourths of all ten-minute radio segments, this study shows. Although Stern and other radio hosts complain about FCC censorship, the number of fines levied by the FCC for indecency have been few compared to the number of graphic, and potentially indecent, sexual discussions in which radio talk show hosts have engaged. As an example, Stern and his co-hosts use words such as "wiener," "prick" (June 26), and "penis" (June 27) without hesitation. The FCC apparently does not consider this language indecent.

When the FCC does determine that shock jocks' language has been indecent, it does not vigorously pursue the cases (McConnell, 1997). A study by the Washington Post of the 93 proposed indecency fines levied by the FCC found that most were "undermined by plodding investigations, insufficient fine amounts and inconsistent follow-up" (Ahrens, 2005, p. A1). The FCC levies fines, but does not collect them. It also willingly renegotiates and lowers the fine, and then allows broadcasters to pay the reduced amount without admitting guilt. As an example, a 1996 Stern interview with adult film actress Jenna Jameson was cited by the FCC for indecency a full year after it was broadcast, and fined just $\$ 6,000$. Four years later, the fine was never paid, so the FCC rescinded it due to "passage of time" (Ahrens, 2005).

Despite the FCC's reluctance to levy and collect fines for indecency, Stern nevertheless claims that the FCC heavily censors what he and others say. During one broadcast, Stern contended, "Censorship is running rampant when it comes to me ...What kills me now is because of the FCC scrutiny of me, I can't say things" (June 27). Despite this assertion, Stern or his co-hosts on June 27 nevertheless referred to a woman as "giv[ing] great oral," used words such as "penis" and "balls" repeatedly, said that he had run "into my dad at a gang bang, a whorehouse," and discussed motel etiquette, which called for "pleasur[ing] yourself in the shower." Stern and other radio personalities appear to be free from FCC censorship, despite claiming that their speech has been sharply curtailed by the FCC. By claiming to be censored, they can appear to be confronting and challenging "big brother." and permission has been granted for this version to appear in e-Publications@Marquette. Taylor \& Francis (Routledge) does not grant permission for this article to be further copied/distributed or hosted elsewhere without the express permission from Taylor \& Francis (Routledge). 
Given the content of Stern's terrestrial radio show, it is difficult to imagine how it will be change in the "unregulated" environment of satellite radio. A future study should examine whether Stern's "unregulated" satellite show is markedly different from his broadcast radio show, or whether Stern's claims of being heavily censored on terrestrial radio were just that-mere claims.

\section{Notes}

- Lawrence Soley (PhD, Michigan State University) is Colnik Professor, Diederich College of Communication, Marquette University, Milwaukee, WI 53233 (E-mail: lawrence.soley@marquette.edu).

- The author would like to thank Holly DeShaw and Aaron Smith for their assistance.

\section{References}

Adelson, A. (1996, June 21). Man behind the scenes at Infinity Broadcasting. New York Times, D5.

Ahrens, F. (2005, November 10). Delays, low fines weaken F.C.C. attack on indecency. Washington Post, A1.

American Decency Association (2004, June). Toyota: Hardcore advertiser of the Howard Stern Radio Show. ADA Newsletter, 1, 3.

Bachman, K. (2004, December 6). Stern cut short on Citadel affils after plugging Sirius. Media Week, 14, 4.

Carlin, J. C. (1976). The rise and fall of topless radio. Journal of Communication, 26(1), 31-37.

Colford, P. D. (1992, July 22). Mel who? That's megawatt Mel Karmazin, head of Infinity Broadcasting. Newsday, 56.

Day, J. (2005, January 6). Citadel turns off "bad-mouthing" Stern. The Guardian, 19.

Eisele, A., and Dufour, J. (2005, August 3) Under the dome. The Hill (Washington, DC), 3.

Fast track. (2004, May 3). Broadcasting and Cable, 134, 6.

Feder, R. (2004, August 3). Mancow ends legal beef with indecency crusader. Chicago Sun-Times, 55.

Feder, R. (2005, August 30). How Infinity stumbled on the road to Mancow. Chicago Sun-Times, 57.

Federal Communications Commission (1973, April 11). In re the apparent liability of station WGLD-FM (73-401). 41 F.C.C. 2nd 919.

Federal Communications Commission (2000, April 28). Notice of apparent liability for forfeiture (DA 00-951). 15 F.C.C. Record 13624.

Federal Communications Commission (2002, October 31). In the matter of Emmis Radio License Corporation: Forfeiture order (DA 01-2937). 17 F.C.C. Record 21697. and permission has been granted for this version to appear in e-Publications@Marquette. Taylor \& Francis (Routledge) does not grant permission for this article to be further copied/distributed or hosted elsewhere without the express permission from Taylor \& Francis (Routledge). 
Federal Communications Commission (2004, February 18). In the matter of Emmis Radio License Corporation: Memorandum opinion and order (DA 04-386). 19 F.C.C. Record 2701.

Feldman, C. (2004). Shock jocks. In C. Sterling (ed.), Encyclopedia of Radio (p. 1261). New York: Fitzroy Dearborn.

Ferguson, A. (2004, July 18). Stern's anti-Bush crusade shouldn't be casually dismissed. Pittsburgh Post-Gazette, B2.

Fisher, D. A., Hill, D. L., Grube, J. W., and Gruber, E. L. (2004). Sex on American television: An analysis across program genres and network types. Journal of Broadcasting and Electronic Media, 48(4), 529-553.

Flint, J. (1992, November 2). FCC's Stern fine: Record $\$ 105,000$. Broadcasting, 122, 55-56.

Goldstein, R. (2000, July 12-18). Celebrity bigots. Village Voice, 12.

Greenberg, B. S., and Busselle, R. W. (1996), Soap operas and sexual activity: A decade later. Journal of Communication, 46(4), 153-160.

Kettmann, S. (1993, November 14). Return of the personality that can stop traffic. San Francisco Chronicle, 58.

Klaassen, A. (2005, August 22). Sirius asking top dollar for spots on Stern show. Advertising Age, 76, 6.

Krebs, A. (1973, March 29). Burch scores fad of "topless radio." New York Times, 94.

Krim, J. (2003, March 13). Pornography prevalent on file-sharing services. Washington Post, E1.

Kunkel, D., Cope-Farrar, K., Biely, E., Maynard-Farinola, W. J., and Donnerstein, E. (2001). Sex on TV (2). Menlo Park, CA: Kaiser Family Foundation.

Lorek, L.A. (2004, July 22). Clear Channel fires back at lawsuit. San Antonio Express-News, $1 \mathrm{E}$

Marcotty, J. (1995, June 5). Tiny KCFE radio adds shock jock Don Imus to its morning lineup. Star Tribune, 1D.

Marinucci, C. (2004, July 1). Stern mobilizes shock jock bloc. San Francisco Chronicle, A1.

McConnell, C. (1997, January 27). FCC indecency review yields few fines. Broadcasting and Cable, 127, 26.

McLellan, D. (2004, September 25). Obituary: Bill Balance, 85, legendary host of provocative radio talk show. Los Angeles Times, B14.

Nguyen, D. (2004, November 24). 4 letters spell end for DJ. St. Petersburg Times, $1 \mathrm{~B}$.

Ostrow, J. (1995, October 2). Offending with a smile is old stuff for Don Imus. Denver Post, F1.

Pardun, C. J., L'Engle, K. L., and Brown, J. D. (2005). Linking exposure to outcomes: Early adolescents' consumption of sexual content in six media. Mass Communication and Society, 8(2), 75-91.

Journal of Promotion Management, Vol. 13, No. 1/2 (2007): pg. 73-91. DOI. This article is @ Taylor \& Francis (Routledge) and permission has been granted for this version to appear in e-Publications@Marquette. Taylor \& Francis (Routledge) does not grant permission for this article to be further copied/distributed or hosted elsewhere without the express permission from Taylor \& Francis (Routledge). 
NOT THE PUBLISHED VERSION; this is the author's final, peer-reviewed manuscript. The published version may be accessed by following the link in the citation at the bottom of the page.

Petrozzello, D. (1996, October 21). Stern generates indecency fine against Richmond station. Broadcasting and Cable, 126, 23.

Premiere Radio Networks (2003, November 24). Premiere Radio Networks renews "The Bob and Tom Show" (press release).

Pugh, C. (2004, July 18). We're in for a rude awakening. Houston Chronicle, E8.

Q101-FM (2003, July 7). Mancow radio interview with Joey Butafuoco, digital archive. Retrieved October 20, 2005 from www.q101.com/interviews/mancow.aspx.

Rahner, M. (2000, August 13). Churning up the radio. Seattle Times, L1. Reichert, T., Lambiase, J., Morgan, S., Carstarphen, M., and Zavoina, S. (1999). Cheesecake and beefcake: No matter how you slice it, sexual explicitness continues to increase. Journalism and Mass Communication Quarterly, 76(1), 7-20.

Reno v. ACLU. 117 S. Ct. 2329 (1997).

Reuters (2005, January 2). Stern off four more stations. Houston Chronicle, A2.

Robinson v. F.C.C. 334 F. 2nd 534 (1964).

Shipler, D. K. (1973, April 24). Sexually explicit radio shows wilt under criticism by F.C.C. New York Times, 1.

Smith, L. (2005, June 19), Catching the Mancow fever. Los Angeles Times, E26.

Sommers-Flanagan, R., Sommers-Flanagan, J., and Davis, B. (1993). What's happening on music television? A gender role content analysis. Sex Roles, 28(11/12), 745-753.

Stern, E! strike deal. (1994, June 6). Broadcasting and Cable, 124, 24.

Stern, C. (1995, July 17). FCC to butt heads with Stern. Broadcasting and Cable, 125, 48.

Stern, H. (Producer). (2002, June 27). The Howard Stern Radio Show. Radio broadcast. New York: Infinity Radio.

Viles, P. (1992, November 2). Stern builds a loyal advertiser following. Broadcasting, 122, 53-54.

Viles, P. (1993a, January 18). Infinity eyes Unistar. Broadcasting and Cable, $123,8$.

Viles, P. (1993b, October 18). A new network giant: Infinity to run Westwood and Unistar. Broadcasting and Cable, 123, 40.

Wallenstein, A. (2005, June 23). Shock jock to depart E! channel. Chicago Sun-Times, 43.

White, K. (1995, May 17). Shock jock pioneer holds no punches. Las Vegas Review-Journal, $1 \mathrm{E}$.

Journal of Promotion Management, Vol. 13, No. 1/2 (2007): pg. 73-91. DOI. This article is @ Taylor \& Francis (Routledge) and permission has been granted for this version to appear in e-Publications@Marquette. Taylor \& Francis (Routledge) does not grant permission for this article to be further copied/distributed or hosted elsewhere without the express permission from Taylor \& Francis (Routledge). 